\title{
THIRD-PARTY INTERVENTION STRATEGIES IN SOLVING INTERPERSONAL CONFLICTS: A REVIEW OF RUSSIAN AND FOREIGN STUDIES
}

\author{
M.R. KHACHATUROVA ${ }^{\mathrm{a}}$
}

${ }^{4}$ National Research University Higher School of Economics, 20 Myasnitskaya str., Moscow, 101000, Russian Federation

\begin{abstract}
Comparative analysis of psychological research on the role of the third party in conflicts in Russian and foreign traditions is presented in this article. The author's classification of the third party's intervention strategies in a conflict based on two criteria is discussed. The first criterion is a degree of the third party's activity in a conflict. The second criterion is the aspect which third party emphasizes in the process of solving a conflict - the relations between disputants and their emotions, or the result of a conflict. Hence, a classification of the third party's intervention strategies in solving interpersonal conflicts can be presented. For example, when a third party's activity is high and the third party emphasizes the relations between disputants and their emotions in the process of solving a conflict, the third party's intervention strategies are facilitative, evaluative, transformative, as well as mediation strategies. When the third party's activity is high and the third party emphasizes the outcome of a conflict, the third party's intervention strategies are pressing, directive, arbitration, problem-solving, and deal-making. Then, when the third party's activity is low and the third party emphasizes the relations between disputants and their emotions in the process of solving conflicts, the third party's intervention strategies are differentiated, narrative, storytelling, and understanding-based. Finally, when third party's activity is low and the third party emphasizes the result of a conflict, the third party's intervention strategies are analytic, neutral, strategic, pragmatic, as well as orchestration strategies. Different strategies of third-party intervention in a conflict and their efficiency are analyzed.
\end{abstract}

Keywords: third party intervention; interpersonal conflict; efficiency of strategies.

Third-party intervention plays a large role in solving interpersonal conflicts. A third party in a conflict is an individual who is external to a conflict situation between two or more dis- putants, and who is involved in solving the conflict.

Conflicts can often be resolved more rapidly, more economically, and at an earlier stage with the help of a third 
party. Third parties may be limited to advising disputants, or they may also be able to make binding decisions for the parties. They may intervene in conflicts between individuals or between groups.

Researchers and practitioners have paid considerable attention to the role of third-party intervention in conflict resolution, the choice of intervention strategies, and their effects for the last two decades. They noted that the literature on third-party intervention in various arenas focuses mostly on four areas: describing intervention, its effects and value, advice to third parties, and the determinants of thirdparty intervention (McGuigan \& Popp, 2007; Wall \& Chan-Serafin, 2010).

Scholars assumed that third-party intervention will influence the ability of a disputant to resolve future conflicts. They emphasized that the process of third-party intervention can develop skills that increase the disputants' efficacy. Disputants gain a better understanding of their own and others' interests during the conflict solving process, which can have positive lasting effects on the relations disputants have with each other and with others (Charkoudian, Ritis, Buck, \& Wilson, 2009; Pincock, 2013).

To achieve their goals third parties have to exercise a measure of control, authority, influence, and trust between a third party and disputants (Gerami, 2009; Stimec \& Poitras, 2009). The stronger the trust between them, the higher the probability of finding a satisfactory solution (Poitras, 2013).

Also researches mentioned such attributes as effort, credibility, confidence, knowledge, authority, originali- ty of ideas, rapport, intelligence, and a sense of humor (Kolb, 1983; Bercovitch \& Houston, 1993).

\section{Third-party intervention strategies in solving interpersonal conflicts: Russian traditions}

There are five forms of third-party intervention in solving interpersonal conflicts traditionally present in Russian studies. They differ in the degree of the third party's control over a decision disputants should make. These forms are arbitrator, mediator, facilitator, observer, and consultant (Dmitriev, Kudryavtsev, \& Kudryavtsev, 1993; Emelyanov, 2000; Gromova, 2001; Khasan \& Sergomanov, 2004; Antsupov \& Shipilov, 2008; Grishina, 2008).

Each form of intervention has its own specificity that exerts an effect on a conflict solving process.

Third parties are the most powerful in cases of arbitration. An arbitrator is a judge; they discuss the conflict with disputants, and then dictate an obligatory solution to the parties.

Hence, arbitration may produce more rapid concessions than mediation (Antsupov \& Shipilov, 2008). Arbitration is a binding formal method of conflict management.

A mediator does not have the power to force the parties to make a binding decision; they can only assist in finding an acceptable solution. The disputants make the final decision independently. A mediator is interested in a favorable solving of a conflict that would satisfy both disputants (Grishina, 2008).

One of the most non-authoritarian intervention roles is a facilitator aimed mainly at facilitating the process without 
getting involved in a discussion and conflict solving (Gromova, 2008).

An observer can prevent disputants from mutual aggression or violation of existing agreements and solutions (Emelyanov, 2000).

A consultant is a qualified and impartial expert acting as a third party. He or she must be a scholar-practitioner or an expert. Consulting is an innovative form of intervention in a conflict. A consultant should define a conflict subject, figure out if the disputants have already solved similar conflicts, and help them find an acceptable solution in a conflict (Antsupov \& Shipilov, 2008).

\section{Third-party intervention strategies in solving interpersonal conflicts: Foreign approach}

Thus, the review of Russian studies shows that authors traditionally consider only from four to five third-party intervention strategies in solving conflicts while foreign scholars have categorized third-party intervention into different types of strategies that may be used in the relationship with the conflict parties (Bercovitch \& Houston, 1993). Approximately twenty have been reported, such as analytic (Birke, 2000), evaluative (Riskin, 1996; Lande, 2000; Della Noce, 2009; Wall \& ChanSerafin, 2014), pressing (Carnevale \& Pruitt, 1992; Lee, Gelfand, \& Kashima, 2014; Wall \& Chan-Serafin, 2014), neutral (Kydd, 2003; Wall \& ChanSerafin, 2014), facilitative (Riskin, 1996; Gabel, 2003; Kressel, 2007), differentiated (Regina, 2000), narrative (Bannink, 2007; Hardy, 2008), evaluative-directive (Abramson, 2004), mediation-arbitration (Ross \& Conlon,
2000), problem-solving (Harper, 2006; Bannink, 2007), strategic (Kressel \& Gadlin, 2009), pragmatic (Alberstein, 2007), storytelling (Pinto, 2000), transformative (Bush \& Folger, 1994; Bannink, 2007; Kressel, 2007), understanding-based (Friedman \& Himmelstein, 2006), dealmaking and orchestration strategies (Kolb, 1985).

I assume that these third party intervention strategies can be considered based on two criteria. The first criterion is the degree of the third party's activity. The second criterion is the aspects emphasized by the third party in the process of solving a conflict - the relations between disputants and their emotions, or the result of a conflict. I suggest that some third parties focus on the substance of a conflict, while others focus on improving the conflict process and the relations between disputants. Hence, a classification of the third party's intervention strategies in solving interpersonal conflicts can be presented (Figure 1).

Comparing the strategies to each other it can be noticed, for instance, that a neutral third party may be not too much involved in the process of negotiation, playing the passive role of the "Orchestrator" in D. Kolb's taxonomy or using analytic strategy in R. Birke's classification.

Different third-party intervention strategies should be specified. J. Wall and S. Chan-Serafin (2014) categorized a third party behavior into pressing, evaluative, and neutral strategies.

Using evaluative strategy is typically adopted by a third party to analyze the cases in a balanced manner, point out the strengths and weaknesses to each side, give opinions, and discuss 
The classification of the third party's intervention strategies in solving interpersonal conflicts

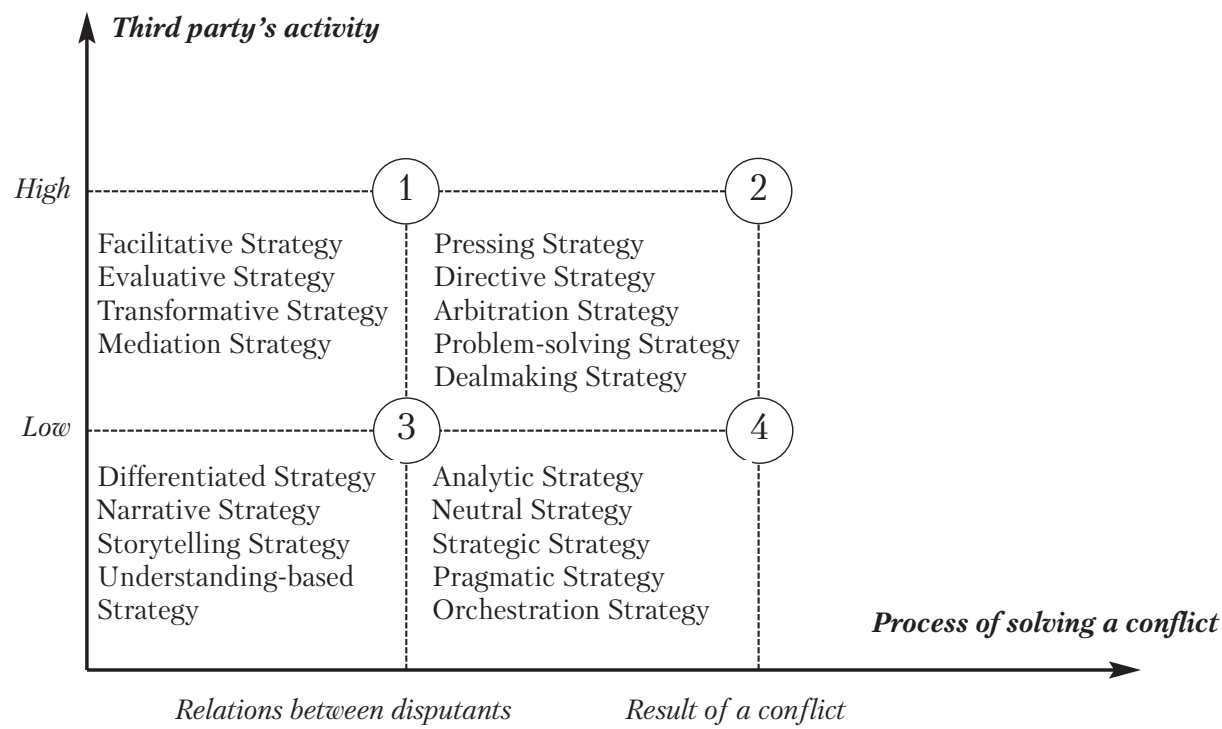

positive or negative aspects of each side's case.

Neutral strategies enable a third party to be impartial, not to evaluate or attempt to move either side off positions, to keep both sides talking, have no interest in the outcome, and not to tell the parties what to do. Using a neutral strategy a third party does not take part in a conflict process but mainly performs the role of an observer.

Pressing strategies constitute the most active form of intervention. A third party attempts to move disputants off current positions pressing one or both sides. A third party tends to be direct and persistent (Wall \& Chan-Serafin 2014). The pressing strategy describes a third party's behavior as criticizing the conflicting parties and making them do what he or she wants them to do.

J. Wall, T. Dunne, and S. ChanSerafin (2011) mentioned that the two assertive strategies - evaluative and pressing - produce significantly more agreements than a neutral strategy.

K. Kressel (2007) classified a third party's behavior in terms of facilitative, evaluative, strategic, and transformative strategies.

In the facilitative strategy a third party focuses primarily on helping the parties identify and express their interests and needs, find a constructive and structured format for dialogue and problem solving.

In the evaluative strategy a third party attempts to provide the parties with a realistic assessment of their negotiating positions.

In the strategic style a third party adopts to address the underlying dysfunction that is fueling the conflict.

In the transformative strategy a third party's attention and activity aim at ascertaining whether there is an 
underlying or latent cause that has fueled the parties' conflict and, if so, they attempt to interest the parties in addressing it (Kressel, 2007, p. 252).

D. Kolb (1994) observed a great number of third parties using various strategies and divided these strategies into two groups named "Dealmakers" and "Orchestrators".

The "Dealmakers" often offer their opinions and make independent suggestions or recommendations. They attempt to control the process and content of negotiations, and to provide additional motivation for the parties to "make the deal".

By contrast, the "Orchestrators" tend to take a more passive role in a conflict preferring that the parties handle the conflict situation themselves with only limited help from the third party (Baker \& Ross, 1992).

Generally, the preference of a third party's intervention strategy is determined by the personal features of the conflicting parties, by reasons that have provoked conflict interactions, and the conflicting parties' behavior. It is important to mention that a third party is always interested in the favorable outcome of conflicts meeting both disputants' wishes.

\section{The effectiveness of the third party's intervention strategies in solving interpersonal conflicts}

The problem of the effectiveness of the third party's intervention strategies in solving interpersonal conflicts is an important area for scholars.

A number of studies (Carnevale \& Pruitt, 1992; Carment \& Rowlands, 1998; Nugent \& Broedling, 2002; De Dreu \& Carnevale, 2003; Loschelder \&
Trotschel, 2010) have mentioned the importance of the third-party's intervention effect in solving interpersonal conflicts.

The third-party's intervention should provide valuable results for the disputants and third parties. The major outcome for the disputants is agreement (Kressel \& Pruitt, 1989; Wall, Stark, \& Standifer, 2001; Hedeen, 2004; Kay, 2009).

Efficacy of a third party's intervention depends on a great number of conditions. One of the ways to evaluate the effectiveness of a third party is to look at the intervention process itself. The disputants come to a conflict solving process with a stunningly diverse array of issues, meanings, experiences, and expectations (McGuigan \& Popp, 2007). The efficacy of a third party may be affected by their choice of intervention strategy.

For instance, a number of studies established that the pressing, directive, and arbitration strategies of a third party more often lead to agreements than the neutral, analytic, and orchestration strategies (Kochan \& Jick, 1978; Carnevale \& Pegnetter, 1985; Hiltrop, 1985; Kressel \& Pruitt, 1989; Wall \& Rude, 1991; Bercovitch \& Houston, 1993; De Dreu \& Carnevale, 2003; Wall et al., 2011).

The pressing, directive, and arbitration strategies are most efficient in a conflict situation when disputants do not have enough time to solve the conflict and are forced to find an immediate solution, and also when disputants know weaknesses and strengths of each other and have no opportunity to find an acceptable solution. These types of strategy are also efficient when disputants are too emotional and aggressive. 
It is possible to use less authoritarian strategies after disputants have calmed down (Grishina, 2008).

By contrast, other researchers found the use of facilitative, narrative, and mediation strategies to be more effective (Burton, 1969; Wissler, 2002; Siqueira, 2003; Mareschal, 2005).

For instance, J. Burton (1969) emphasized the importance of facilitative strategies in overcoming perceptual barriers and contributing to solving a conflict. Likewise, J. Wall and S. ChanSerafin (2014) mentioned that individuals prefer to have control over their actions and have a negative emotional reaction when someone attempts to constrain their personal freedom, and puts pressure on them.

Hence, it is doubtful whether there will ever be a third party's intervention strategy that is effective in all kinds of situations. D. Kolb reported the determinative influence of circumstances on a third party's stylistic behavior (Kolb, 1983).
Thus, the issue of the effectiveness of a third party's intervention in a conflict remains rather disputable.

\section{Conclusion}

In summary, it can be noted that the variety of third-party intervention strategies need to be categorized. I suggest two criteria for classification - the degree of the third party's activity and aspects that third party emphasizes in the process of solving a conflict. One of the limitations of my review can be in the fact that there are other criteria that can be used for the categorization such as effectiveness of the thirdparty's intervention, the degree of disputants' activity, and others.

I suppose that these findings could be extended in further research by focusing on additional contexts of the third-party's intervention context domestic, organizational, or international. It will also allow a possibility of generalizing these findings.

\section{References}

Abramson, H. I. (2004). Problem-solving advocacy in mediations. Dispute Resolution Journal, 59, 56-64. Alberstein, M. (2007). Forms of mediation and law: cultures of dispute resolution. Ohio State Journal on Dispute Resolution, 22, 321.

Antsupov, A. Y., \& Shipilov, A. I. (2008). Konflictologiya [Conflictology]. Saint Petersburg: Piter.

Baker, C., \& Ross, W. H. (1992). Mediation control techniques: a test of Kolb's "orchestrators" vs. "dealmaker" model. The International Journal of Conflict Management, 3(4), 319-341.

Bannink, F. P. (2007). Solution-focused brief therapy.Journal of Contemporary Psychotherapy, 37(2), 87-94.

Bercovitch, J., \& Houston, A. (1993). Influence of mediator characteristics and behavior on the success of mediation in international relations. International Journal of Conflict Management, 4(4), 97-321.

Birke, R. (2000). Evaluation and facilitation: moving past either/or. Journal of Dispute Resolution, 55(2), 247-293.

Burton, J. W. (1969). Conflict and communication. London: Macmillan.

Bush, R. A., \& Folger, J. P. (1994). The promise of mediation. San Francisco: Jossey-Bass.

Carment, D., \& Rowlands, D. (1998). Three's company: evaluating third-party intervention in intrastate conflict. The Journal of Conflict Resolution, 42, 572-599. 
Carnevale, P. J., \& Pegnetter, R. (1985). The selection of mediation tactics in public-sector disputes: a contingency analysis. Journal of Social Issues, 41, 65-81.

Carnevale, P. J., \& Pruitt, D. G. (1992). Negotiation and mediation. Annual Review of Psychology, 43, $111-133$

Charkoudian, L., Ritis, C., Buck, R. \& Wilson, C. L. (2009). Mediation by any other name would smell as sweet or would it? The struggles to define mediation and its various approaches. Conflict Resolution Quarterly, 26(3), 293-316.

De Dreu, C., \& Carnevale, P. J. (2003). Motivational bases of information processing and strategy in negotiation and social conflict. Advances in Experimental Social Psychology, 35, 235-291.

Della Noce, D. J. (2009). Evaluative mediation: in search of practice competencies. Conflict Resolution Quarterly, 27(2), 193-214.

Dmitriev, L. I., Kudryavtsev, V. N., \& Kudryavtsev, N. V. (1993). Vvedenie v obshchuyu teoriyu konfliktov [Introduction to general theory of conflicts]. Moscow: Russian Academy of Sciences.

Emelyanov, S. M. (2000). Praktikym po konfliktologii [Practical work in conflictology]. Saint Petersburg: Piter.

Friedman, G., \& Himmelstein, J. (2006). Resolving conflict together: the understanding-based model of mediation. Journal of Dispute Resolution, 2, 523-554.

Gabel, S. (2003). Mediation and psychotherapy: two sides of the same coin? Negotiation Journal, 19, $315-328$

Gerami, A. (2009). Bridging the theory-and-practice gap: mediator power in practice. Conflict Resolution Quarterly, 26(4), 433-451.

Grishina, N. V. (2008). Psikhologiya konflikta [Psychology of a conflict]. Saint Petersburg: Piter.

Gromova, O. N. (2001). Konflictologiya [Conflictology]. Moscow: Tandem.

Hardy, S. (2008). Mediation and genre. Negotiation Journal, 24, 247-268.

Harper, C. (2006). Mediator as peacemaker: the case for activist transformative-narrative mediation. Journal of Dispute Resolution, 2, 595.

Hedeen, T. (2004). The evolution and evaluation of community mediation: limited research suggests unlimited progress. Conflict Resolution Quarterly, 22, 101-133.

Hiltrop, J. M. (1985). Mediator behavior and the settlement of collective bargaining disputes in Britain. Journal of Social Issues, 41, 83-99.

Kay, J. (2009). Home settling: foreclosure mediation grows, but some wonder if it's the best. $A B A$ Journal, 95, 14-17.

Khasan, B. I., \& Sergomanov, P. A. (2004). Psikhologiya konflikta i peregovory [Psychology of conflicts and negotiations]. Moscow: Academia.

Kochan, T. A., \& Jick, T. (1978). The public sector mediation process. Journal of Conflict Resolution, 22, 209-240.

Kolb, D. M. (1983). The mediators. Cambridge, MA: MIT Press.

Kolb, D. M. (1985). To be a mediator: expressive tactics in mediation. Journal of Social Issues, 41, 1-25.

Kolb, D. M. (1994). When talk works: Profiles of mediators. San Francisco: Jossey-Bass.

Kressel, K. (2007). The strategic style of mediation. Conflict Resolution Quarterly, 24, 251-283.

Kressel, K., \& Gadlin, H. (2009). Mediating among scientists: a mental model of expert practice. Negotiation and Conflict Management Research, 2, 308-343.

Kressel, K., \& Pruitt, D. G. (1989). Mediation research. San Francisco: Jossey-Bass.

Kydd, A. (2003). Which side are you on? Bias, credibility, and mediation. American Journal of Political Science, 47, 597-611. 
Lande, J. (2000). Toward more sophisticated mediation theory.Journal of Dispute Resolution, 2, 321-333.

Lee, T. L., Gelfand, M. J., \& Kashima, Y. (2014). The serial reproduction of conflict: third parties escalate conflict through communication biases. Journal of Experimental Social Psychology, 54(1), 68-72.

Loschelder, D., \& Trotschel, R. (2010). Overcoming the competitiveness of an intergroup context: thirdparty intervention in intergroup negotiations. Group Processes and Intergroup Relations, 13, 795-815.

Mareschal, P. M. (2005). What makes mediation work? Mediators' perspectives on resolving disputes. Industrial Relations, 44, 509-517.

McGuigan, R., \& Popp, N. (2007). The self in conflict: the evolution of mediation. Conflict Resolution Quarterly, 25(2), 221-238.

Nugent, P., \& Broedling, L. (2002). Managing conflict: third-party interventions for managers. The Academy of Management Executive, 16, 139-155.

Pincock, H. (2013). Does mediation make us better? Exploring the capacity-building potential of community mediation. Conflict Resolution Quarterly, 31(1), 3-30.

Pinto, J. (2000). Peacemaking as ceremony: the mediation model of the Navajo nation. International Journal of Conflict Management, 11(3), 267-286.

Poitras, J. (2013). The strategic use of caucus to facilitate parties' trust in mediators. International Journal of Conflict Management, 24(1), 23-39.

Regina, W. (2000). Bowen systems theory and mediation. Conflict Resolution Quarterly, 18, 111-128.

Riskin, L. L. (1996). Understanding mediators' orientations, strategies, and techniques: a grid for the perplexed. Harvard Negotiation Law Revier, 1, 7-51.

Ross, W. H., \& Conlon, D. E. (2000). Hybrid forms of third-party dispute resolution: theoretical implication of combining mediation and arbitration. Academy of Management Review, 25, 416-427.

Siqueira, K. (2003). Conflict and third-party intervention. Defense and Peace Economics, 14(6), 389-400.

Stimec, A., \& Poitras, J. (2009). Building trust with parties: are mediators overdoing it? Conflict Resolution Quarterly, 26(3), 317-331.

Wall, J. A., \& Chan-Serafin, S. (2010). Do mediators walk their talk in civil cases? Conflict Resolution Quarterly, 28(1), 3-21.

Wall, J. A., \& Chan-Serafin, S. (2014). Friendly persuasion in civil case mediations. Conflict Resolution Quarterly, 31(3), 285-303.

Wall, J. A., Dunne, T. C., \& Chan-Serafin, S. (2011). The effects of neutral, evaluative, and pressing mediator strategies. Conflict Resolution Quarterly, 29(2), 127-150.

Wall, J. A., \& Rude, E. D. (1991). The judge as a mediator. Journal of Applied Psychology, 76, 54-59.

Wall, J. A., Stark, J. B., \& Standifer, R. L. (2001). Mediation: a current review and theory development. Journal of Conflict Resolution, 45, 370-391.

Wissler, R. L. (2002). Court-connected mediation in general civil cases: what we know from empirical research. Ohio State Journal on Dispute Resolution, 17, 641-680.

Milana R. Khachaturova - associate professor, Faculty of Social Sciences, School of Psychology, Department of General and Experimental Psychology and academic director of post-graduate school in psychology, National Research University Higher School of Economics, Ph.D.

E-mail: mhachaturova@hse.ru 


\title{
Стратегии вмешательства третьей стороны в разрешение межличностных конфликтов: обзор российских и зарубежных исследований
}

\author{
М.P. Хачатурова ${ }^{a}$ \\ ${ }^{a}$ Национальньй исследовательский университет «Высшая школа экономики», 101000, Россия, \\ Москва, ул. Мясницкая, д. 20
}

\section{Резюме}

В статье представлен сравнительно-психологический анализ отечественных и зарубежных исследований роли третьей стороны в разрешении конфликтов. Обсуждается авторская классификация стратегий вмешательства третьей стороны в конфликт, основанная на двух критериях. Первый критерий - это степень активности третьей стороны в конфликте. Второй критерий - аспект, подчеркиваемый третьей стороной в процессе решения конфликта, - отношения между участниками конфликта и их эмоции или результат конфликта. Таким образом, может быть представлена классификация стратегий вмешательства третьей стороны в процесс разрешения межличностного конфликта. Например, когда активность третьей стороны высока и третья сторона акцентирует свое внимание на отношениях между конфликтующими сторонами и их эмоциями в процессе решения конфликта, стратегиями вмешательства третьей стороны являются фасилитативная, оценочная, трансформирующая стратегии и стратегия посредничества. Когда активность третьей стороны высока, но третья сторона ориентируется на результат конфликта, стратегиями вмешательства третьей стороны могут быть - директивная стратегия, стратегии прессинга, арбитража, решения проблем и стратегия активного вмешательства в конфликт («dealmaking» в классификации Д. Колба). Далее, когда активность третьей стороны низка и третья сторона подчеркивает отношения между конфликтующими сторонами и их эмоции в процессе разрешения конфликта, стратегиями вмешательства третьей стороны являются дифференцирующая, нарративная, описывающая стратегии и стратегия, основанная на понимании ситуации. Наконец, когда активность третьей стороны низкая и третья сторона подчеркивает результат конфликта, стратегиями вмешательства третьей стороны могут быть аналитическая, нейтральная, стратегическая, прагматичная стратегии и стратегия пассивного наблюдения («orchestration» в классификации Д. Колба). В статье также проанализирована эффективность различных стратегий вмешательства третьей стороны в конфликт.

Ключевые слова: вмешательство третьей стороны, межличностный конфликт, эффективность стратегий.

Хачатурова Милана Радионовна - доцент, факультет социальных наук, департамент психологии, кафедра общей и экспериментальной психологии, академический директор аспирантской школы по психологии, Национальный исследовательский университет «Высшая школа экономики», кандидат психологических наук.

Контакты: mhachaturova@hse.ru 